\title{
Of Mermaids and Changelings: Human Rights, Folklore and Contemporary Irish Language Poetry
}

\author{
Rióna Ní Fhrighil \\ NUI Galway, Ireland
}

Copyright (c) 2017 by Rióna Ní Fhrighil. This text may be archived and redistributed both in electronic form and in hard copy, provided that the author and journal are properly cited and no fee is charged for access.

\begin{abstract}
This article investigates the intersection of human rights discourse, Irish folklore and contemporary Irish-language poetry. The author contends that contemporary Irishlanguage poets Louis de Paor and Nuala Ní Dhomhnaill exploit the multi-faceted nature of international folklore motifs, along with their local variants, to represent human rights violations in their poetry. Focusing specifically on the motif of the changeling in De Paor's poetry and on the motif of the mermaid in Ní Dhomhnaill's, the author traces how folklore material is reimagined in ways that eschew uncomplicated transnational solidarity but which engender empathetic settlement.
\end{abstract}

Key Words. Irish-Language Poetry, Mermaid, Changeling, Evil Eye, Empathy, Universal Human Rights, Acts of Witnessing.

Resumen. En este artículo se estudia la intersección entre el discurso sobre los derechos humanos, el folclore irlandés y la poesía contemporánea escrita en gaélico. La autora afirma que algunos poetas actuales que escriben en la lengua original de Irlanda, especialmente Louis de Paor y Nuala Ní Dhomhnaill, hacen uso frecuente de motivos del folclore internacional, valiéndose de la naturaleza poliédrica de los mismos, así como de su manifestación en el caso irlandés, con el objeto de representar en sus poemas violaciones de los derechos humanos. La autora se centra en el motivo del niño cambiado al nacer, en el caso de De Paor, y en el de la sirena en el caso de Ní Dhomhnaill, para analizar cómo el material tomado del folclore popular se reescribe siguiendo patrones que huyen de una complicada solidaridad transnacional aunque buscan una formulación que genere empatía.

Palabras clave. Poesía escrita en gaélico, sirena, niño cambiado al nacer, mal de ojo, empatía, derechos humanos universales, ser testigo.

The interdisciplinary field of human rights and contemporary literature is a burgeoning sphere of research as evidenced by recent major publications including Theoretical Perspectives on Human Rights and Literature (Goldberg and Schultheis Moore 2011) and The Routledge 
Companion to Literature and Human Rights (McClennen and Schultheis Moore 2016). The content of both publications attest to the dominance of narrative fiction in the analysis of literary representations of human rights issues. The intersection of poetry and human rights discourse as well as oral traditions and human rights discourse receive much less critical attention. It is this intersection of human rights discourse, poetry and folklore that is the focus of this article. The reimagining of folklore material is a recognised feature of much contemporary Irish-language poetry. With the notable exception of Nic Eoin ("Scéal"), the extent to which contemporary Irish-language poetry engages thematically with international human rights violations has, however, yet to be fully appreciated. An initial survey of the twentieth and twenty-first century corpus yields in excess of one hundred poems which refer to humanitarian crises and human rights violations including poems about the Holocaust, the Vietnam War, the Gulf War, the Bosnian War and the ongoing Israeli-Palestinian conflict. By focusing specifically on the folklore motifs of the mermaid and the changeling in the poetry of Nuala Ní Dhomhnaill and Louis de Paor respectively, this article will consider how oral traditions influence the form and content of Irish-language human rights poetry and to what end. Furthermore, it will be argued that the human rights discourse is a valuable critical lens in the discussion of twentieth and twenty-first century Irish-language poetry.

Although acknowledging that the relation between literature and human rights is "at once logical and fraught", editors of The Routledge Companion, Sophia McClennen and Alexandra Schultheis Moore, insist on the importance of examining "its ongoing and productive dialectical relationship" (2). Joseph Slaughter contends that the evolution of human rights discourse is intertwined with literary history. In his comprehensive study, tellingly entitled Human Rights, Inc.: The World Novel, Narrative Form, and International Law (2007), Slaughter traces the rise of the Bildungsroman as a literary form which expounded a normative conception of the human individual and the development of human rights discourse emphasising a free and full human subjectivity, describing them as "mutually enabling fictions ... as each projects an image of the human personality that ratifies the other's idealistic vision" (4). More recent research by Hadji Bakara, however, has emphasised the inter-relatedness of poetry and international human rights declarations. Bakara outlines how Archibald MacLeish, a poet and politician centrally involved in the drafting of the preamble to the United Nations Charter (1945) and the preamble to the Universal Declaration of Human Rights (1948), resorted to poetic form to explore the tensions between the personal and the impersonal, the metaphysical and the ontological at the heart of the UDHR. Bakara argues that a close reading of one of MacLeish's draft preambles, written in lineated poem form and employing parataxis to define the subject of the Declaration, clearly indicates MacLeish's suspicion of the language of human rights based on divine or natural law (522523). Bakara calls for a re-evaluation of the role of poetry in relation to human rights discourse and concludes his article as follows: "Seeing poetry as an escape from rather than a vehicle for bestowing upon us 'inalienable truth' thus enables a poetics of human ever more crucial to the survival of human rights today" (537).

This "poetics of human" and an alertness to issues of social justice is at the heart of much of Louis de Paor's poetic oeuvre (Mac Giolla Léith 259-261). De Paor's keen awareness of Ireland's colonial history is matched by an acute understanding of its complicity with colonizing powers, both past and present. Poems such as "An Dubh ina Gheal"/"Assimilation" (AGBR 80-81), "Didjeridu" (AGBR 82-85) and "Oileán na Marbh"/“The Isle of the Dead" (AGBR 86-99) address themes of colonisation by white Europeans, including the Irish, and the subjugation of indigenous Australians and their culture. Ireland's complicity in modern-day U.S. imperialistic operations is explored in the poems "Haiku briste do Róisín Dubh" (CSA 63) (which translates as "A Broken Haiku for Dark Rosaleen") and "Gnóthaí eachtracha"/“Foreign Affairs" (BCNT 134-143), both of which 
reference the use of Shannon Airport by U.S. troops, while the poem "Fáilte Uí Dhonnchú"/“O'Donoghue's Welcome” (AGBR 196-199) criticises both the Irish Government's response and the seeming indifference of the general population to the plight of Romanian refugees who came to Ireland in unprecedented numbers in the late 1990s.

This appreciation of the connectedness of global politics coupled with an uneasiness at the privileged position of the Western citizen is explored in the poem "Iarlais" "Changeling" (SSU 32; AGBR 132-133). The poem clearly references the Vietnam War and more specifically Nick Ut's famous photograph, taken on 8 June 1972, entitled "The Terror of War" or more popularly known as "the Napalm girl". The photo itself, which was awarded the Pulitzer Prize in 1973, was controversial because it depicted full frontal nudity of a young female victim (Hariman \& Lucaites 171-207). De Paor's poem, originally published in his 1996 collection Seo. Siúd. Agus Uile. attests to the iconic status of the photograph. The speaker of the poem involuntarily recalls the horrific image of the burning, naked child when his own daughter, undressed for the bath, returns screaming because the bath water is too hot:

I bhfaiteadh na súl, ghaibh an iarlais uimpi cló muirneach m'iníne is rith isteach sa tsíoraíocht uaim ar bhóthar gan cheann i Vítneam Theas, chomh lomnocht le súil gan fora, gan luid uirthi a cheilfeadh a cabhail thanaí ar mo shúil mhillteach nuair a chaoch an ceamara leathshúil dhall uirthi. (SSU 32)

\author{
In the blink of an eye, \\ the changeling had taken on \\ my daughter's beloved form, \\ running away from me \\ into eternity \\ on an unending road \\ in South Vietnam, \\ bare as an unlidded eye, \\ without a stitch \\ to protect her nakedness \\ from my evil eye \\ when the camera winked \\ a blind eye at her, like this. \\ (AGBR 133)
}

Just as the child of the famous photograph functions as a metonym of war-time suffering, the narrator of the poem is metonymic of the consumers of war-time suffering and human rights crises captured in war photography. In the final stanza, the father-narrator expresses both his sense of guilt and personal responsibility for inadvertently inflicting temporary pain on his own child who is crying and also for casting an exploitative eye on the child whose image he consumed:

Nuair a nochtann tú chugam ag scréachaíl le tinneas, tá taise a cló buailte ar do chraiceann fliuch, loiscthe ag an uisce fiuchta ag allas scólta mo shúl. (SSU 32)

\author{
When you come back to me \\ screaming with pain, \\ the scars of the other one \\ are printed on your dripping skin, \\ burned by boiling water \\ that sweats from my scalded eyes. \\ (AGBR 133)
}

Although "Iarlais"/“Changeling" has been described as "a lovely little poem", "dán beag gleoite" (Ó Conchubhair 20), there is undoubtedly something deeply unsettling about this poem. That unsettling or troubling element is inextricably linked with the sophisticated reimaging of two folklore motifs - the motif of the evil eye and of the changeling. A closer 
examination of how these motifs are employed by the poet will reveal just how complex and self-reflexive this poem is.

The changeling motif (F321.1) is predominantly a Germanic and Celtic one, although some examples have been found in East, West and North Africa, Asia and Australia. In summary, the changeling is the sickly infant left by the "good people" who steal the healthy human child. The changeling resembles the human baby but is identified by one or a combination of the following attributes: constant crying; insatiable appetite; unusual physical features - oversized heads or deformed limbs; dark wrinkled or wizened skin. They are generally mute - refusing to speak or laugh unless tricked into doing so - and changelings sometimes exhibit supernatural powers or musical talents (Mac Philib). Changelings generally do not walk or run unless they think they are not being observed (Schoon Eberly 234). To recover the human child, the changeling must be made cry, be beaten or burned, thrown on the fire or on a dunghill, or left to drown, although in most accounts to no avail since the original child is not returned. Parental inattentiveness or indeed negligence is implied by the changeling motif - the "good people" or the fairies would not succeed in swapping the child who was properly supervised or whose parents took the appropriate precautions (Munro 255). Indeed, it is this motif of parent culpability, and more specifically female culpability, that is explored in Nuala Ní Dhomhnaill's poems "Thar mo chionn" (FS 72-74), meaning "On my behalf", and in the poem "An Bhatráil" (F 14), meaning "The Beating", although it is beyond the scope of this paper to analyse these.

Evidently "Iarlais"/"Changeling" references many of these themes: the seemingly healthy child who is transformed into a screaming and physically injured changeling; adult cruelty which entails scalding as well as parental negligence and thus complicity in the child's misfortunes. The poem, however, is much more than a poetic reimagining of relevant folklore material. The poet exploits the ambiguities at the heart of the folktales about changelings to bring into sharper focus important questions about the representation and consummation of images of distant atrocities and human rights violations.

A further consideration of the changeling motif in folklore sources, for example, reveals that it entails competing claims of victimisation: the healthy child is the obvious victim of the swap, but the bereft parent is also a victim; the changeling who becomes the focus of the parents' anger and grief is scapegoated. Contrary to traditional lore which emphasised supernatural malevolence and therefore vindicated the parent, the narrator of the poem acknowledges his own complicity: he was in charge and his daughter "did as she was told/ And put her two arms/ Over her head/ While I pulled off/ Her too-tight jumper"; "chuir sí a dá láimh/ in airde go humhal/ gur bhaineas di/ a geansaí róchúng" (AGBR 132-133). He allowed her run to the bath and it was his evil eye that blinked her and his own tears that left burn-marks on her skin.

Susan Schoon Eberly interprets changeling lore in general as folk representations of disabilities and she argues convincingly that many changeling stories correspond to medically-acknowledged stages of grief (231-233). The majority deal with the first and second stages of grief: parents' initial denial and then the anger and guilt of the second stage. Relatively few deal with acceptance, "perhaps because for many of these little changechildren, acceptance would be preceded by the child's natural or unnatural death ..." (233). Thomas O'Grady understands the final verse of the poem to be restorative: "the poet may yet have his guilt assuaged, even absolved, by those heartfelt brimming tears - tears of empathetic fatherly love" (26). It would appear, however, that De Paor's poem is closer to the majority of folklore sources and stops short of acceptance or restoration. The father-narrator remains haunted not only by the original image of Kim Phúc, but moreover by what that implies for him as a father, as a relatively privileged human and as a consumer of media stories. 
A further consideration is the representation of the child in the poem. The poet draws on rhetorical power of the child as innocent victim whose human rights have been violated. This is a literary device found in other Irish-language poems including "Mo bheirt Phailistíneach"/"My Two Palestinians" by Michael Davitt (18-19), "Cáilín, Cúig Bliana Déag, as Baghdad ag inse a scéil" (which translates as "A Fifteen Year Old Girl from Baghdad Telling her Story") by Cathal Ó Searcaigh (55-65) and "Suantraí Sarah is Asmahane"/“Sarah and Asmahane's Lullaby" by Liam Ó Muirthile (288-291). Although the changeling motif itself embodies the unattractive and the shadow side of the innocent child, De Paor does not deconstruct the idea of the innocent child victim in this poem. This is indicative of the tendency in Western discourse to idealise and to objectify the innocent child while ignoring his/her potential for subversive agency (Higonnet; Hesford). Paradoxically, writings by Vietnam veterans identified the young female as the most deadly civilian enemy, exactly because she was to them the most unlikely perpetrator (Higonnet 1566).

Although the title of the poem focuses the reader's attention on the changeling motif, the motif of the evil eye (D2064.4) is arguably of greater literary significance. The act of looking, seeing and consuming images is a central theme in this poem with the word "súil"/ "eye" repeated five times in the text. Beliefs about the evil eye are of course of great antiquity and are found internationally (Elworthy). Essentially, it is the conviction that harm can be done to a person, animal or object simply by looking or glancing at it in a certain way. In some cases possession of the evil eye was associated with certain types of people: unmarried mothers wed during pregnancy or those who were incorrectly baptised - that is to say who deviated from the community's moral code. In other cases the possession of the evil eye was involuntary; one category of possessors were fathers who inadvertently cast it on their children (Borsje and Kelly 3), as the narrator does in the poem "Iarlais"/"Changeling". By referencing both the iconic photograph which swayed public opinion about the Vietnam war as well as the motif of the evil eye, the poet foregrounds the tension between the potential of visuals to mobilize empathy and the risk of uncritical or indifferent voyeurism.

From a human rights perspective, the use of the evil eye motif as a metaphor for the problematic and exploitative potential of the witnessing gaze is in keeping with more recent pleas for what Wendy Kozol calls "ethical spectatorship", that is "forms of representation that foreground the dialogic interactions between ethical looking and the role of spectacle in transnational visual witnessing of human rights crises" (Kozol 166). Indeed, the poem "Iarlais"/"Changeling" anticipates Susan Sontag's treatise on the need to critically reflect on what it means to look at images of war and to interrogate the feelings that they arouse, especially feelings of sympathy and/or empathy:

The imaginary proximity to the suffering inflicted on others that is granted by images suggests a link between the faraway sufferers - seen close-up on television screens and the privileged viewer that is simply untrue, that is yet one more mystification of our real relations to power. So far as we feel sympathy, we feel we are not accomplices to what caused the suffering. Our sympathy proclaims our innocence as well as our impotence. To that extent, it can be (for all our good intentions) an impertinent - if not an inappropriate - response. To set aside the sympathy we extend to others beset by war and murderous politics for a reflection on how our privileges are located on the same map as their suffering, and may - in ways we might prefer not to imagine - be linked to their suffering, as the wealth of some may imply the destitution of others, is a task for which the painful, stirring images supply only an initial spark. (Sontag 92) 
In her discussion of "Iarlais"/“Changeling”, Máire Ní Annracháin contends that the changeling as metaphor "makes the horror of changelings available as a way of indicating empathy with the people of Vietnam; and, further, it makes an ethical connection between the poet and the suffering girls by eliminating the physical distance between them: a changeling is found in one's own family, on one's own hearth" (116). When the motif of the changeling and of the evil eye are considered together, however, the distance is arguably accentuated rather than eliminated. The speaker of the poem acknowledges that the suffering of the young girl in the picture is of a different magnitude to that of his daughter; he considers the mediated nature of the representation of human rights violations, the uneven power relations between those directly affected and those who witness from a safe distance and he is troubled by his relatively privileged position as a voyeur, as one who has the liberty of interpreting this image in the context of his own experience and ideological position. The poet apparently does not seek to evoke an uncomplicated sense of transnational solidarity but instead espouses what Dominick LaCapra's has termed as "empathetic unsettlement"; that is a form of writing which draws attention to the distance between the empathiser and the one who has suffered, as well as foregrounding the mediated nature of the other's suffering (xi). Indeed, the changeling of the title may well refer to the poem itself which, no more than the iconic photograph to which it refers, is yet another inauthentic substitute - just like the changeling itself. De Paor apparently foregrounds the poem's inauthenticity, painfully aware of the limits of representation and of the risk of the poem perpetuating the pornography of violence.

The aesthetic and ethical considerations foregrounded in "Iarlais"/"The Changeling" by De Paor are probed less from an overtly political and more from a psychological perspective by Nuala Ní Dhomhnaill through the extended metaphor of the mermaid. Indeed, the most ambitious and sustained re-imagining of folklore motifs and material from the oral tradition in twentieth and twenty-first century Irish-language poetry is to be found in Ní Dhomhnaill's poetry (Nic Eoin, “Athscríobh"). More so that any of Ní Dhomhnaill's preceding anthologies, her fourth Irish-language anthology entitled Cead Aighnis (1998) thematicises large-scale human rights violations and interrogates a number of related themes including forced mass migration, cultural assimilation, cross-cultural encounters and transnational empathy (Ní Fhrighil, "The Mermaids"; Nic Eoin, Trén 284-320). The international folklore motif of the mermaid (ML 4080) is prominent in this collection of poems and particularly in the extended sequence of thirty-three poems entitled "Na Murúcha a Thriomaigh" and subsequently translated by Paul Muldoon as "The Assimilated Merfolk" (FMM 27). Before discussing the mermaid motif in more detail, I wish to draw attention to the role of folklore material in shaping the architectonics of Ní Dhomhnaill's poetry collections, Cead Aighnis in particular.

As with all of Ní Dhomhnaill's Irish-language anthologies, Cead Aighnis is prefaced with a folktale which encompasses the main themes of the collection. The introductory folktale, which includes a reference to Ní Dhomhnaill's great grand-mother, illustrates the Gnostic belief that a person had three souls: the breathing soul, the feeling soul and the immortal soul, and that it was the immortal soul that stayed with the individual until death (CA 7). The anthology itself is tripartite, with poems grouped in separate sequences of varying length. The first series, entitled "An Máistir Dorcha" (which translates as "The Dark Master"), contains fifty poems which collectively explore various aspects of death and conquest as themes (see De Paor, "An Máistir"). Notably, this sequence includes a number of poems that refer specifically to international human rights violations; "Dubh"/"Black" subtitled "On the fall of Srebenice, 11 July, 1995" (CA 15; FMM 16-19) and "An Obair"/“The Task" (CA 31; FMM 20-21) which references the massacre of Muslim children in Algeria in the mid-1990s as well as the war-time crimes of an unnamed Serbian poet, possibly Radovan Karadžić. The middle sequence of poems is entitled "Aistriúcháin", meaning "Translations", 
and contains eight translations to Irish of poems by Paul Celan, Michael Longley, Tom MacIntyre, Medb McGuckian and Ferida Duraković. These are all twentieth-century poets who witnessed, first-hand, conflict zones. This short sequence acts as a bridge between the two longer sequences. The third and final sequence which will be discussed in more detail below is titled "Na Murúcha a Thriomaigh". This sequence of thirty-three poems examines the precarious existence of merpeople who have abandoned their natural marine habitat and whose flight from sea to land, as the framing folktale of the original anthology implies, was actually a journey through death. Paul Muldoon translates the title as "The Assimilated Merfolk" (FMM 27). Other possible translations based on the denotations of the verb "triomaigh" include "the merpeople who dried up", or "the merpeople who were washed ashore" or "the merpeople who were left high and dry" or "merpeople who fell silent".

Remarkably, Ní Dhomhnaill's dual language anthologies do not preserve these formal structures; the framing folktale is never reprinted in translation and the poems are not always grouped in thematic sequences as in the original anthologies. As noted previously by Kaarina Hollo and Philip O'Leary, the centrality of folklore material as a structuring principle bringing an overarching thematic unity to the anthologies is therefore not very evident to the English-language reader. The dual language anthology The Fifty Minute Mermaid (2007) contains thirty-six poems translated to English by Paul Muldoon out of the original ninety-one of Cead Aighnis and consists of two sequences; a three poem "Part One" and a thirty-seven poem "Part Two". The middle sequence of translated poems, which like the mermaids themselves are on the move to a new linguistic and cultural context, is absent from the dual language anthology. This change of emphasis is discernible in critical readings of Ní Dhomhnaill's work that emphasise the centrality of folklore motifs and of intertextual references to folklore material while applying different critical lenses to the mermaid sequence, including feminist literary theory (De Paor, Tionscnamh; Nic Dhiarmada), postcolonial literary theory (Ní Fhrighil, "The Mermaids"; Biathra), psychology theories pertaining to assimilation and culture shock (Nic Eoin, Trén 284-320) and theories of liminality (Ní Shíocháin). International scholars including Hiroko Ikeda and Cary Shay have favoured interpretations based on psychoanalytical literary theory, possibly prompted by the title of the dual language anthology which clearly references the psychotherapist's hour.

As already noted, the international folktale "The Seal Maiden Legend" or "The Seal Woman" (ML 4080) is central to the sequence "Na Murúcha a Thriomaigh"/"The Assimilated Merfolk". Folklorist Bo Almqvist suggests that the "The Man who Married the Mermaid" is a more fitting title for the versions found in Ireland (5). Local variations of the international tale are mostly found in coastal counties on the West coast of Ireland (Lysaght 161) and the version Ní Dhomhnaill heard from a neighbour has been described by Almqvist "as a fairly typical Kerry version" (31). It is the story of a farmer who comes upon a mermaid brushing her hair on the seashore. He steals her cap and, unable to return to the sea without it, she is forced to follow him home. They marry, have children, and then one day, after seven years on land, her husband throws the hidden cap down from the loft by mistake and she immediately retrieves it and returns to the sea (Almqvist 53).

The main themes of this folktale are evident in an early poem by Ní Dhomhnaill, "An Mhaighdean Mhara", published in her first collection An Dealg Droighin (1981) and subsequently translated in Selected Poems/Rogha Dánta (1988) by Michael Hartnett as "The Mermaid". Speaking in the first person, the mermaid laments her sense of otherness and recounts the physical and psychological consequences of defying the natural law and by implication the mores of the community:

Má tá eireaball éisc féin orm nílim gan dathúlacht éigin.
Though I've got a fishes tail

I'm not unbeautiful: 
Tá mo ghruaig fada is buí

is tá loinnir ó m'ghainní

ná chífeá riamh ag mná mhíntíre.

Dath na gcloch an tsúil acu

ach féach go cúramach isteach

i m'mhogailse

is chífir an burdán fearna

is róinte groí

ag macnas

i m'mhac imreasáin.

Ní gan pian

a thángas aníos

ar thalamh.

Do bhriseas

an slabhra réamhordaithe,

do mhalairtíos snámh

ar luail cosa,

ag priocadh liom

ar nós na gcuirliún.

Creid uaim gur grá, ní Dia, a dhein é a ordú.

(DD 81-82) my hair is long and yellow

and there's a shine from my scales

you won't see on landlocked women.

Their eyes are like stones

but look into these eyes of mine

and you will see the sturgeon

and you will see fine seals

gambolling in my pupils.
Not without pain
have I landed:
I broke
the natural law.
I swapped swimming
for walking on earth,
picking my steps
like a curlew.
Believe you me,
it was love, not God
who gave the order.
(RD 53)

Of note is the fact that Ní Dhomhnaill included in this early poem a pointed reference to the physical abuse of the mermaid in an attempt by her husband's relatives to break her stubborn silence, a motif unique in Kerry to the version told by Blasket Islander, Peig Sayers (Almqvist 28-30). The type of abuse alluded to in the poem, however, differs in magnitude from that of the folktale, as the mermaid claims "we have ways of making you talk'/ I hear in Gestapo accents/ (water goes down and down/ but no tide nears me)" (RD 53); “"tá slite againn chun tú a chur ag caint'/ á chlos agam i dtuin Gestapo; imíonn an t-uisce síos is síos/ is ní thagann aon taoide i m'aice $(D D$ 81).This reference to the Gestapo conjures up images of waterboarding and connects the mermaid motif, for the first time in Ní Dhomhnaill's poetry, with large-scale human rights violations, not only of an individual but of an ethnic group.

It is interesting to consider how Ní Dhomhnaill revised and reworked the mermaid metaphor in the intervening years culminating in the mermaid sequence of thirty-three poems that documents different aspects of the mermaids' struggle to make the transition to life on land in Cead Aighnis. Unlike the earlier poem which gives the mermaid's personal perspective of her situation, the merpeople of this sequence do not speak in the first person. A narrator, whose connection to the merpeople is unspecified, observes them and their antics in a very detached manner, sometimes cautiously sympathetic as in the poems "Cuimhne an Uisce"/"A Recovered Memory of Water" (CA 120; FMM 30) and "An Mhurúch san Ospidéal"/“The Mermaid in the Hospital" (CA 105; FMM 35) and sometimes repulsed by their seeming cruelty, especially to female offspring in poems like "Briseadh an Tí"/"Wrecking the House" (CA 138; FMM 119) and "An Mhurúch agus a Tigh"/"The Mermaid and Her House" (CA 141-142; FMM 125). The multiple distances between the narrator and the mermaids, including cultural, linguistic, generational and emotional distances, are dramatized in the poem "Admháil Shuaithinseach"/“A Remarkable Admission": 
Aon uair amháin riamh i mo shaol a fuaireas oiread is an leide is lú ó bhéal aon duine acu

go raibh saghas éigin cineghlanadh gafa tríd acu

is gur ó áit éigin eile ar fad, i bhfad i gcéin

a thángadar. (CA 124)
Only one time ever in my life

did I get as much as the slightest inkling from one of them

that they had gone through some sort of ethnic cleansing

and that it was to some other place altogether, far, far away, they really belonged. (FMM 87)

The narrator, then a young teenager fascinated by science and the rational mind, meets an older man of merpeople stock on the seashore who proffers an alternative view of reality:

'Níl aon ainmhí dá bhfuil ar an míntír,' ar sé, 'nach bhfuil a chomh-mhaith d'ainmhí sa bhfarraige. An cat, an madra, an bhó, an mhuc,

tá siad go léir ann.

Go dtí an duine féin, agus tá sé sin ann leis.

'Sé ainm atá air siúd ná an mhurúch.'
'There's not a single animal up on dry land that doesn't have its equivalent in the sea. The cat, the dog, the cow, the pig.

They're all there.

Right up to the human being himself, and he's there too.

The name they call him is the sea-person.
Ghluais scamall dorcha thar a shúile ar dhath na dtonn

a dhein tiompáin mhara dhíobh.

N'fheadar cad a shnámhaigh anall is anonn

sna duibheagáin doimhne sin

mar sara raibh am agam i gceart

é a bhodhradh le mo chuid cleatrála is le mo chaint

ar cheimic, fisic, is ar fhiosrúcháin mhuireolaíochta

do chas sé ar a shál is d'imigh uaim.

D'fhág sé ar snámh mé idir dhá uisce.

(CA 124-125)
A dark cloud passed over his sea-green eyes

that made them look like marine trenches.

I'll never know what strange creatures swam around

in their great depths

because, just when I was about to launch into him

and bend his ear

about chemistry, physics and the latest underwater explorations

He turned on his heel and disappeared.

He left me hanging there,

like a drowned man between two seams of water. (FMM 87/89)

The role of the narrator as mediator in this sequence appears to personify the act of empathising as understood in cognitive terms: "trying to imagine a view of the world that one does not share" (Cameron, qtd. in Winter 414). Rather than an emotional response based on immediacy, on closing the gap between the human rights subject and the witness, a cognitive and affective response is dependent on distance, on transmission and on reciprocity (Winter 416-417). In foregrounding the tense and unequal relationship between individual mermaids and the narrator in this sequence, Ní Dhomhnaill prefigures Sarah Winter's proposed definition of empathy as a medium which in the realm of human rights aesthetics "would thus involve bridging not just the difference between self and other but also ... the disparity of 
rights and security between the citizen or witness to the atrocity and the person whose rights are violated" (419).

The power differential and the resulting hostility between the narrator and the mermaids is played out in the poem Irish title "An Mhurúch agus Focail Áirithe"/"The Mermaids and Certain Words" as the mermaid tries to hide her origins, dismissing sea-life as anachronistic and as a source of embarrassment:

Níl aon namhaid eile aici

ach an saol fó-thoinn a chleacht sí

sarar iontaigh sí ar a hathshaol ar an míntír

a chur i gcuimhne dhi. Séanann sí ó bhonn

go raibh oiread is cac snioga de bhaint aici leis

aon am. 'Ní raibh aon tsuim riamh agam

sna piseoga sin, nó in aon sórt seanaimserachta.

Aer, eolas, solas gléineach na heolaíochta

is ea a shantaíos-sa.' (CA 118)
She hates nothing so much

as being reminded of the underwater life that she led

before she turned over a new leaf on dry land. She totally

denies

that she had the slightest connection with it

at any time. 'I never had any interest

in those old superstitions, or any of the old traditions.

Fresh air, knowledge, the shining brightness of science

are all I ever hankered after.' (FMM 77)

The narrator, however, interjects and directs the reader's attention to folklore sources which do not corroborate the mermaid's personal narrative:

Ba chuma liom ach go bhfuaireas-sa amach

san eitheach í.

Istigh sa Roinn le Béaloideas Éireann,

tá lámhscríbhinní iomlán de Bhailiúchán na Scol breactha óna láimh,

scríte in uisce, le clipe de sciathán rotha, ar scothóg feamainne mar phár. (CA 118)
I wouldn't mind one way or the other but I myself have

found her out

in the deception.

In the Department of Irish Folklore in University College,

Dublin,

there is a whole manuscript in the Schools' Collection

that was set down by her, written in water, with the fin of a ray for a pen,

on a long scroll of kelp. (FMM 77/79)

When confronted, the mermaid initially denies her involvement and then dismisses it as homework forced upon her by the school master, the narrator adding cynically: "She would prefer to suffer a heavy nosebleed/ rather than admit she ever had a hand in its composition" (FMM 79); "Chaithfeadh sí fuil shróine/ sara mbeadh sí riamh admhálach ina thionscnamh" (CA 119).

Here, as in other poems, the accuracy and authenticity of the mermaids' testimony is questioned and the concept of truth in relation to human rights violations is destabilized. "Cuimhne an Uisce"/"A Recovered Memory of Water" (CA 120; FMM 30-33) and "Melusine" (CA 146; FMM 136-39) further attest to the mermaids' conscious suppression of 
memory in order to survive. Poems such as "Bunmhiotas na Murúch"/"Founding Myth" ( $C A$ 109; FMM 44-47) and "Miotas Bunaidh Eile"/“Another Founding Myth" (CA 110; FMM 4851) attest to their collective attempts to bring narrative order to their experience through acts of composition and story-telling while poems like "Na Murúcha ag Ní a gCeann"/"The Merfolk and Washing Hair" (CA 114; FMM 64-67), "Na Murúcha agus an Bainne Cíche"/"The Merfolk on Breastfeeding" (CA 107; FMM 40-43) and "Murúch Linbh gan Baisteadh"/“An Unbaptised Merchild" (CA 123; FMM 84-85) convey the extent to which traditional beliefs inherent in the oral tradition continue to shape the mermaids' understanding of reality, especially at those threshold or liminal points in life such as childbearing, baptism, marriage or death. The very fact that their personal truth as well as their modes of narration are at odds with the narrator's preference for hard facts serves to underline the vulnerability of the human rights subject whose terms of reference and cultural codes may not map neatly on to those of the host culture. Collectively these poems also serve to highlight the power differential between oral and literate cultures and the greater validity or authenticity associated with written testimonies.

The human rights violation that led to the merpeople's flight from the sea is not specifically named or described in the sequence. This can be understood as further evidence of the unutterable and unrepresentable nature of traumatic events (Nic Eoin, Trén 308-312; Shay 1). A human rights lens proffers yet another reading: the inarticulation of the rights violation in the sequence is in keeping with the fact that the mermaids themselves are not fully human, as the narrator claims in "Na Murúcha agus an Bainne Cíche"/"The Merfolk and Breastfeeding": "however we might describe/ what they'd morphed into, it certainly wasn't human beings" (FMM 43); "pé sort dúile eile a dhein díobh, níor dhein daoine díobh" (CA 108). As subjectivities who are liminal, neither fish nor fowl, non-normative or what Judith Butler refers to as the "spectrally human" (89), their rights and thus the violations of those rights are not generally rendered audible, legible and intelligible in socio-economic, political and legal contexts. Although the narrator (and the reader) remain vague with regards the initial crisis that effected the mermaids" displacement, poems like "An Mhurúch san Ospidéal"/"The Mermaid in the Hospital" bring personal stories into sharper focus as the mermaid of the poem wakes up post-operation to find that she now has two legs which she must learn to use:

Dhúisigh sí

agus ní raibh a heireaball éisc ann

níos mó

ach istigh sa leaba léi

bhí an dá rud fada fuar seo.

Ba dhóigh leat gur gaid mhara iad nó sláimicí feola. (CA 105)
She awoke

to find her fishtail

clean gone

but in the bed with her

were two long, cold thingammies.

You'd have thought they were tangles of kelp or collops of ham. (FMM 35)

The physical transformation is only the beginning of the mermaid's journey as she learns to walk and to develop a new sense of self:

An bhanaltra a thug an nod di is a chuir í i dtreo an eolais -

'Cos í seo atá ceangailte díot agus ceann eile acu anseo thíos fút.

Cos, cos eile,

a haon, a dó.

Caithfidh tú foghlaim
It was the sister who gave her the wink and let her know what was what.

'You have one leg attached to you there and another one underneath that.

One leg, two legs ...

A-one and a-two ...

Now you have to learn 
conas siúl leo.’

Ins na míosa fada

a lean

n'fheadar ar thit a croí

de réir mar a thig

trácht na coise uirthi,

a háirsí? (CA 105) what they can do'.

In the long months

that followed

I wonder if her heart fell

the way her arches fell,

her instep arches. (FMM 35/37)

The genesis of this poem is worth exploring. It is not, as one might expect, based on folklore material but instead is a lineated translation of a brain-damaged patient's case history recounted by neurologist Oliver Sacks in The Man Who Mistook His Wife for a Hat and Other Clinical Tales (2011: 59-62). Ní Dhomhnaill's appropriation of this material may at first glance seem arbitrary, but the preface to Sacks's collection of clinical tales is worthy of attention. Sacks contends:

There is no subject in a narrow case history; modern case histories allude to the subject in a cursory phrase, which could as well apply to a rat as a human being. To restore the human subject at the centre - the suffering, afflicted, fighting human subject - we must deepen a case history to a narrative or tale: only then do we have a who as well as a 'what', a real person, a patient in relation to the physical ... Empirical science, empiricism takes no account of the soul, no account of what constitutes and determines personal being. (42)

This of course echoes the framing folklore story of Ní Dhomhnaill's anthology and its emphasis on the multidimensional nature of the human being, the individual's three souls. It also echoes Primo Levi's concerns about the limited nature of documentary testimonials which cannot capture the "depths of a human being"; he contends "for this purpose the dramatist or the poet are more appropriate" (99-100). Furthermore, James Dawes states that:

Human rights work is, at the heart, a matter of storytelling. Many of the most recognizable organisations that intervene in humanitarian crises do so in large part by using language instead of food, medicine, or weapons; the most important act of rescue for them is not delivering supplies but asking questions, evaluating answers, and pleading with those of us who observe from a distance. (Dawes 394)

In a lecture delivered in 2009 to the Irish Human Right's Commission, Seamus Heaney famously called on all artists to be citizens of the "Republic of Conscience"; to conceive of their art as moral hearing aids which would let the screams of injustice be heard above the "noise" of spin (Heaney 15). Louis de Paor and Nuala Ní Dhomhnaill are keenly aware of the ethical duty that according to Heaney "shadows the aesthetic vocation" (8), although their poetry avoids the rhetoric of transnational solidarity in favour of an aesthetic that foregrounds the multiple distances and the power differentials between the empathiser and the one who has suffered. Folklore motifs based on non-normative subjectivities and which eschew clearcut positions, thus not allowing for easy identification or an uncomplicated sense of empathy, are particularly suited to the poetics of the human at the heart of the human rights poems discussed. Both poets show a keen appreciation of the multifaceted nature of folklore sources, although the mining, interrogating and re-imagining of folklore material is much more sustained in Ní Dhomhnaill's poetics. Attuned to the connectedness of global politics, they both re-imagine international folklore motifs, inflected by local variations, in ways that 
parallel and sometimes precede debates in human rights discourse about the universality of the human rights subject, the act of witnessing and the authenticity of testimonials, as well as the mediation of human rights stories and images.

\section{Abbreviations}

$A G B R=$ De Paor, Louis. Ag Greadadh Bas sa Reilig: Clapping Hands in the Cemetery. Indreabhán: Cló Iar-Chonnacht, 2005.

$C A=$ Ní Dhomhnaill, Nuala. Cead Aighnis. Daingean: An Sagart, 1998.

$C S A=$ De Paor, Louis. Cúpla Siamach an Ama. Baile Átha Cliath: Coiscéim, 2006.

$D D=$ Ní Dhomhnaill, Nuala. An Dealg Droighin. Baile Átha Cliath: Cló Mercier, 1981.

$F=$ Ní Dhomhnaill, Nuala. Feis. Maigh Nuad: An Sagart, 1991.

$F S=$ Ní Dhomhnaill, Nuala. Féar Suaithinseach. Maigh Nuad: An Sagart, 1984.

$F M M=$ Ní Dhomhnaill, Nuala. The Fifty Minute Mermaid . Oldcastle: Gallery Press, 2007.

$B C N T=$ De Paor, Louis. The Brindled Cat and the Nightingale's Tongue. Bloodaxe Books, 2014.

$R D=$ Ní Dhomhnaill, Nuala. Rogha Dánta/ Selected Poems. Dublin: Raven Arts Press, 1988.

$S S U=$ De Paor, Louis. Seo. Siúd. Agus Uile. Baile Átha Cliath: Coiscéim, 1996.

\section{Works Cited}

Almqvist, Bo. "Of Mermaids and Marriages". Béaloideas 58 (1990): 1-74.

Bakara, Hadji. "Poetry in the Shadow of Human Rights". American Literary History 28.3 (2016): 512-541.

Borsje, Jacqueline and Fergus Kelly. “The Evil Eye' in Early Irish Literature and Law”. Celtica 24 (2003): 1-39.

Butler, Judith. Precarious Life: The Powers of Mourning and Violence. New York: Verso, 2004.

Davitt, Michael. Selected Poems/Rogha Dánta. Dublin: Raven Arts Press, 1987.

Dawes, James. That the World May Know: Bearing Witness to Atrocity. Cambridge, Mass: Harvard University Press, 2007.

De Paor, Louis. Ag Greadadh Bas sa Reilig: Clapping Hands in the Cemetery. Indreabhán: Cló Iar-Chonnacht, 2005.

De Paor, Pádraig. Tionscnamh Filíochta Nuala Ní Dhomhnaill. Baile Átha Cliath: An Clóchomhar, 1997. . "An Máistir Dorcha”. Féilscribhinn do Chathal Ó hÁinle. Eds. Eoin Mac Cárthaigh and Jürgen Uhlich. Indreabhán: An Clóchomhar, 2012. 89-112.

Elworthy, Fredrick Thomas. "Evil Eye". Encyclopaedia of Religion and Ethics V. Ed. James Hastings. Edinburgh, New York: T. and T. Clark, Charles Scribner Sons, 1937. 608615.

Goldberg, Elizabeth Swanson and Alexandra Schultheis Moore, eds. Theoretical Perspectives on Human Rights and Literature. New York: Routledge, 2011.

Hariman, Robert and John Louis Lucaites. No Caption Needed: Iconic Photographs, Public Culture, and Liberal Democracy. Chicago: The University of Chicago Press, 2007.

Heaney, Seamus. Writer \& Righter. Dublin: Irish Human Rights Commission, 2010.

Hesford, Wendy S. "Contingent Vulnerabilities: Child Soldiers as Human Rights Subjects". The Routledge Companion to Literature and Human Rights. Eds. Sophia A. McClennen and Alexandra Schultheis Moore. New York: Routledge, 2016. 69-77. 
Higonnet, Margaret. "Child Witness: The Case of World War I and Darfur". PMLA 121.5 (2006): 1565-1576.

Hollo, Kaarina. "From the Irish: On The Astrakhan Cloak". New Hibernia Review 3.2 (1999): 129-141.

Ikeda, Hiroko. “Toward our own 'Murúch': Reading Nuala Ní Dhomhnaill's 'The Fifty Minute Mermaid"”. Journal of Irish Studies 25 (2010): 36-47.

Kozol, Wendy. "Complicities of Witnessing in Joe Sacco's Palestine." Theoretical Perspectives on Human Rights and Literature. Eds. E. Goldberg and A. Schultheis. New York: Routledge, 2011. 165-179.

LaCapra, Dominick. Writing History, Writing Trauma. Baltimore: John Hopkins University Press, 2000.

Levi, Primo. Moments of Reprieve. Trans. Ruth Feldman. London: Abacus, 1987 (1981).

Lysaght, Patricia. "Bealtaine: Irish Maytime Customs and the Reaffirmation of Boundaries". Boundaries \& Thresholds. Ed. Hilda Ellis Davidson. Woodchester: Thimble Press, 1993. 28-43.

Mac Giolla Léith, Caoimhín. "Louis de Paor". Filíocht Chomhaimseartha na Gaeilge. Ed. Rióna Ní Fhrighil. Baile Átha Cliath: Cois Life, 2010. 254-270.

Mac Philib, Séamas. "The Changeling (ML 5058) [sic] Irish Versions of a Migratory Legend in Their International Context". Béaloideas 59 (1991): 121-131.

McClennen, Sophia A. and Alexandra Schultheis Moore, eds. The Routledge Companion to Literature and Human Rights. New York: Routledge., 2016.

Munro, Joyce Underwood. "The Invisible Made Visible: The Fairy Changeling as a Folk Articulation of Failure to Thrive in Infants and Children". The Good People: New Fairylore Essays. Ed. Peter Narváez. Lexinton: University Press of Kentucky, 1997. 251-283.

Ní Annracháin, Máire. "Reading the Gaelic Poetry of Ireland and Scotland". Modern Irish and Scottish Poetry. Eds. Peter Mackay, Edna Longley and Fran Brearton. Cambridge: Cambridge University Press, 2001. 102-118.

Ní Dhomhnaill, Nuala. The Fifty-Minute Mermaid. Oldcastle: Gallery Press, 2007.

Ní Fhrighil, Rióna. "The Mermaids on Land: the Exile of the Irish at Home and Abroad in the Poetry of Nuala Ní Dhomhnaill'. The Representation of Ireland/s. Images From Outside and From Within. Ed. Rosa González. Barcelona: Universitat de Barcelona, 2003. 145-155.

. Briathra, Béithe agus Banfhilí. Baile Átha Cliath: An Clóchomhar, 2008.

Ní Shíocháin, Tríona. "An tairseachúlacht bhuan agus múnlú na suibiachta i nuafhilíocht na Gaelainne". LÉANN 4 (2016): 63-84.

Nic Dhiarmada, Bríona. Téacs Baineann, Téacs Mná: Gnéithe de Fhilíocht Nuala Ní Dhomhnaill. Baile Átha Cliath: An Clóchomhar, 2005.

Nic Eoin, Máirín. "Athscríobh na miotas: gné den idirthéacsúlacht i bhfilíocht chomhaimseartha na Gaeilge". Taighde agus Teagasc 2 (2002): 23-47.

. "Scéal an Tuirimh Nua-Aoisigh: Téama na Cogaíochta i Nua-Fhilíocht na Gaeilge". Aistí ag Iompar Scéil: in ómós do Shéamus P. Ó Mordha. Ed. Breandán Ó Conaire. Baile Âtha Cliath: An Clóchomhar, 2004. 207-227.

. Trén bhFearann Breac: An Díláithriú Cultúir agus Nualitríocht na Gaeilge. Baile Átha Cliath: Cois Life, 2005.

Ó Conchubhair, Brian. "Luathfhilíocht Louis de Paor”. Comhar 61.8 (2001): 18-20.

O'Grady, Thomas. "Found in Translation II: Louis de Paor's 'Language Question'”. The Boston Irish Reporter 16.9 (2005): 26.

O’Leary, Philip. “Wounds and Triumphs”. Irish Literary Supplement 18.1 (1999): 12. 
Ó Muirthile, Liam. An Fuíoll Fea: Rogha Dánta/ Wood cuttings: New and Selected Poems. Baile Átha Cliath: Cois Life, 2013.

Ó Searcaigh, Cathal. Aimsir Ársa. Galway: Arlen House, 2013.

Shay, Cary A. "Of Mermaids and Others: Remarkable Revelations in 'The Fifty Minute Mermaid"'. Nordic Irish Studies 9 (2010): 1-12

Schoon Eberly, Susan "Fairies and the Folklore of Disability: Changelings, Hybrids, and the Solitary Fairy". The Good People: New Fairylore Essays. Ed. Peter Narváez. Lexinton: University Press of Kentucky, 1997. 227-250.

Slaughter, Joseph R. Human Rights, Inc. New York: Fordham University Press, 2007.

Sontag, Susan. Regarding the Pain of Others. London: Penguin, 2004.

Sacks, Oliver. The Man Who Mistook His Wife For a Hat. London: Picador, 2011 (1985).

Winter, Sarah. “'Inverted Sympathy': Empathy and Mediation in Literary Transactions of Human Rights". The Routledge Companion to Literature and Human Rights. Eds. Sophia A. McClennen \& Alexandra Schultheis Moore. New York: Routledge, 2016. 414-426.

Received: 29 April 2017 Revised version accepted: 24 July 2017

Rióna Ní Fhrighil is a lecturer in Modern Irish in NUI, Galway. She is the author of the book Briathra, Béithe agus Banfhilí: Filiocht Eavan Boland agus Nuala Ní Dhomhnaill (2008), a comparative study of the poetry of Eavan Boland and Nuala Ní Dhomhnaill. She is editor of a collection of essays on contemporary Irish-language poetry Filiocht Chomhaimseartha na Gaeilge (2010) and co-editor of a collection of essays on literary translation Aistriú Éireann (2008). She is the Principal Irish-language Investigator on the major research project "The Representations of Jews in Irish Literature", funded by the Arts and Humanities Research Council, UK.

riona.nifhrighil@nuigalway.ie 